This is a pre-copyedited, author-produced PDF of an article accepted for publication in Notes and Queries following peer review. The definitive publisher-authenticated version [Notes and Queries (2007) 54 (3): 265-272. doi: 10.1093/notesj/gjm139] is available online at: http://nq.oxfordjournals.org/content/54/3/265.2.extract.

\title{
WHY A DOG? A LATE DATE FOR THE TWO GENTLEMEN OF VERONA
}

The date of Shakespeare's The Two Gentlemen Of Verona is one of the most uncertain in the canon. The only text we have is that in the Folio of 1623, there is no record of a performance until the eighteenth century, and no topical allusions have been found within the text. The only indisputable fact about dating is that the play is mentioned in Francis Meres's Palladis Tamia: Wit's Treasury, dedicated 19 October 1598, and entered in the Stationers' Register on 7 September of that year. It is generally believed that the play is 'early', but in the absence of hard evidence for a date of composition, editors have ranged between 1588 and 1595 in their dating, and recent editors candidly admit that whatever the date chosen the actual dating and placing remain more or less informed guesswork" and "the play could belong to any year in the decade before Meres mentioned it ${ }^{2}$.

The belief that Two Gentlemen is an early play of Shakespeare's is largely based on the judgement that the style, characterisation and dramatic technique of the play are relatively poor for Shakespeare, and that therefore the play is early. This has proved a slippery foundation for dating, as Jeffrey Masten has noted: "it falls early in Shakespeare's career, and so it is a bad play" often shades imperceptibly into "it is a bad play and so it falls early in Shakespeare's career". ${ }^{3}$ The assumption that the play is early has also necessitated some critical contortionism. Although placed early, Two Gentlemen is nevertheless acknowledged to share features with Shakespeare plays thought to be later. As a result, we get the suspicious situation that Two Gentlemen has to be seen as a 'seminal' work that 'anticipates' many later works ${ }^{4}$ (or later works are seen to 'return to' it over an over again ${ }^{5}$ ).

I shall argue in this paper that the general belief that Two Gentlemen is an early work of Shakespeare's is wrong. I shall suggest that the play was written sometime after the middle of 1597, in which case it does not 'anticipate' features of 'later' plays such as Romeo and Juliet and The Merchant of Venice, but more likely borrows from them. Far from Two Gentlemen containing no topical allusions whatsoever, I suggest it was in part written as a satire on one of the most notorious events of the late 1590s. This connection may have gone unnoticed simply because no one till now has looked for topical allusions in the play in the years after 1595 .

In a paper in Notes and Queries in 1981, J.J.M. Tobin argued that in writing Two Gentlemen Shakespeare was clearly influenced by Thomas Nashe's Have With You To Saffron-Walden. Since Nashe's work was published in 1596, Tobin concluded that we should change the prevailing view that Two Gentlemen is one of Shakespeare's earliest works. ${ }^{6}$ 
Despite the obvious strength of Tobin's argument, no one has ever taken it very seriously. In the latest Arden edition of the play, William C. Carroll simply notes Tobin's paper without commenting on it. ${ }^{7}$ The entrenched belief that Two Gentlemen is an early play has doubtless had some impact on this neglect of Tobin's work, but Tobin's presentation of his own material has probably been a factor as well, as he did not explore in detail the full implications of his own arguments.

Tobin noted firstly that the names of the characters Valentine, Sebastian, Panthino, Thurio, Don Alphonso, Don Antonio and Launce in Two Gentlemen were not found in acknowledged sources for the play, but did appear in Have With You. Secondly, he noted a surprisingly large number of instances in Two Gentlemen where words or phrases that were unique or rare in Shakespeare were also to be found in Have With $\mathrm{You}$, and, most significantly, that there were even sequences of distinctive words common to both works:

Instances of common diction unique or rare in Shakespeare together with sequences of words similarly distinctive add to the impression created by the presence of the proper nouns, that Shakespeare had read Saffron-walden as he was composing The Two Gentlemen of Verona. Among these terms are 'beadsman' (I. i. 18), 'metamorphis'd' (I. i. 66), 'noddy' (I. i. 112, 115), 'Light o' Love' (I. ii. 80), 'month's mind' (I. ii. 134), 'wench . . . puling ... water in an urinal' (II. i. 23, 25, 39, 40), 'cur ...a Jew' (II. iii. 9, 11), 'paragon' (II. iv. 146), 'braggardism' (II. iv. 164), 'alehouse' (II. v. 7, 54), lubber' (II. v. 45), 'round hose' (II. vii. 54), 'cate-log' (III. i. 274), 'dump' (III. ii. 84), 'villains', 'beard', 'riches', 'sojourned', 'tongues', 'linguist', (IV. i. 5, 10, 13, 33, 55), 'spaniel-like . . fawneth' (IV. ii. 14-15), 'nick' (IV. ii. 76), 'cur', 'taught', 'hang'd', 'company', 'chamber' whip/whips', 'hang', and 'executed' (IV. iv. $1,10,21,5,15,17,19,29,24,25,28,22$, and 32), and 'postern' (V. i. 9) and 'forest' (V. i. 11). Compare Nashe's words and phrases in Saffron-walden: 'beadsman' (SW, 42), 'metamorphized' (74), 'Noddy' (133), 'light a love' (85), 'months-mind' (72), 'puling wench' (113), 'water cast in an urinall' (112), 'a Jew . . a curre' (106), 'Paragons' (42), 'Bragganisme' (109), 'alehouse' (132), 'lubberly' (85), 'round hose' (38), 'catalogue' (17), 'tongues' (14), 'linguist' (15), 'villanie' (15), 'sojournd' (15), 'bearded ${ }^{l}$ (15), 'rich . . Riches' (14), and 'like a spaniels ... fawne' (33), 'nicke' (42), 'companie' (106), 'curre' (106), 'hang-man' (106), 'taught' (106), 'executed' (106), 'chamber' (107), and 'whippets' (107), 'posternes' (91), and 'forrest' (92).

Even without further commentary, this list is very impressive. However, if we examine some of the items listed in more detail the possibility that Two Gentlemen was influenced by Have With You becomes hard to ignore.

Consider, for example, the clustering of the words 'wench . . puling . . water in an urinal' in II, i, 23-40 of Two Gentlemen, which parallels the close connection of 'puling wench' and 'water cast in an urinall' on pages 112 and 113 of Have With You. ${ }^{8}$ A search of LION $^{9}$ shows that Two Gentlemen is the only play of this period in which 'puling' is in close proximity to 'wench', and that it is also the only play of this period containing the phrase 'water in an urinal'. The rarity of these two sequences of words individually would be enough to make us suspect that their use in both Two 
Gentlemen and Have With You is not coincidental. The fact that they also occur within close proximity of each other in both works can hardly be due to chance. ${ }^{10}$

Consider, further, the two longest clusters of words in Two Gentlemen that parallel a cluster in Have With You, the 'villains', 'beard', 'riches', 'sojourned', 'tongues', 'linguist', (IV. i. 5, 10, 13, 33, 55) group, and the 'cur', 'taught', 'hang'd', 'company', 'chamber', whip/whips', 'hang', and 'executed' (IV. iv. 1, 10, 21, 5, 15, 17, 19, 29, 24, 25, 28, 22, and 32) group. Tobin's simple listing of Act, Scene and Line numbers without further explication disguises the fact that both these clusters are in scenes of Two Gentlemen which were probably late, or even last-minute, additions to the play, the first cluster coming in a scene involving the Outlaws, and, most significantly, the second cluster coming entirely within Lance's final soliloquy.

Because of its many textual inconsistencies, it has long been recognised that Two Gentlemen was probably 'put together in some haste' ${ }^{11}$, and that Lance and his dog Crab were last-minute additions to the play - the result of 'second thoughts' ${ }^{12}$ or 'some sort of afterthought" 13 . If so, it seems unlikely to be coincidence that the longest cluster of words in Tobin's list happens to occur in Lance's final soliloquy about the outrageous misbehaviour of Crab. Instead, it looks suspiciously like Shakespeare for some reason may have gone deliberately to Have With You for inspiration in writing this part of Two Gentlemen.

Such a suspicion is heightened if we examine one of the words that Tobin lists as common to Two Gentlemen and Have With You, the word 'noddy'. 'Noddy' meant 'simpleton' or 'fool' in Elizabethan usage, and Tobin himself offers no comment on it. However, if we look at the usage and placement of the word in Two Gentlemen and Have With You we can see that it occupies a very special place in both.

In Two Gentlemen, the word 'noddy' is not just a stray usage by Shakespeare, but forms the basis of an extended wordplay in Act 1 , Scene $1^{14}$ :

Proteus:

But what said she?

Speed:

I.

Proteus:

Nod-I, why that's noddy.

Speed:

You mistooke Sir: I say she did nod;

And you aske me if she did nod, and I say I.

Proteus:

And that set together is noddy.

Speed:

Now you haue taken the paines to set it together, take it for your paines. 
Proteus:

No, no, you shall haue it for bearing the letter.

Speed:

Well, I perceiue I must be faine to beare with you.

Proteus:

Why Sir, how doe you beare with me?

Speed:

Marry Sir, the letter very orderly,

Hauing nothing but the word noddy ${ }^{15}$ for my paines.

This running joke on the word 'noddy' has never been satisfactorily glossed - no editor of Two Gentlemen has offered any explanation as to why exactly Shakespeare makes such lengthy play on this word, nor made anything of the fact that he chose to do so in the very first scene of the play. Leech comments that the joke 'grows tiresome ${ }^{16}$, an indication that it is likely we have lost some topical allusion here that was obvious to Shakespeare's audience.

In Have With You, as in Two Gentlemen, 'noddy' is not just an isolated usage by Nashe, but part of a lengthy discourse on the word itself:

O o yes, be it knowne, I can ryme as wel as the Doctor, for a sample whereof, in stead of his

Noddy Nash, whom everie swash, and

his occasional admonitionatiue Sonnet, his Apostrophe Sonnet, and tynie titmouse Lenuоy...In stead of all these (I say) here is the tufft or labell of a rime or two... They are to the tune of Labore Dolore... If you hit it right, it will go maruellous sweetly.

Gabriel Haruey, fames duckling, hey noddie, noddie, noddie:

Is made a gosling and a suckling, hey noddie, noddie, noddie. ${ }^{17}$

Nashe is responding here to Gabriel Harvey's rhyme on 'noddy Nash' in Pierce's Supererogation:

I am euer prone to hope, as I wish, euen the best of the worst: and although wilfull Malice be a stiffe, and stubberne aduersary to appease, yet I haue seene a greater miracle, then the pacification of Paper-warres, or the attonement of Inkhorne foes. There She standeth, that with the finger of Industry, and the toungue of Affability, hath acheiued some straunger woonders, vpon as rough, and harsh fellowes, as

The noddy Nash, whom euery seruing Swash With pot-iestes dash, and euery whip-dog lash: 
(for the ryme is more famous, then was intended): and with the same causes emprooued, why may She not directly, or violently accomplish the same effectes? or what is impossible to the persuasiue, and Patheticall influence of Reason, and Affection? ${ }^{18}$

Clearly, Harvey's use of the phrase 'noddy Nashe' in Pierce's Supererogation had annoyed Nashe. 'Noddy' may have become something of a nickname for Nashe. This might explain an otherwise obscure passage about Nashe's days at Cambridge in Richard Lichfield's The Trimming of Thomas Nashe:

...[he] had a hand in a Show called Terminus \& non terminus, for which his partener in it was expelled the Colledge: but this foresaid Nashe played in it (as I suppose) the Varlet of Clubs; which he acted with such naturall affection, that all the spectators tooke him to be the verie same. ${ }^{19}$

In the Elizabethan period, 'Noddy' was also the name of a particular card game, and the name for the Knave (or Varlet) in various card games. ${ }^{20}$ Lichfield's description of Nashe as being a 'natural' for the Varlet of Clubs may be another way of calling him 'Noddy'. If Shakespeare's inclusion of a running joke on the word in the first scene of Two Gentlemen is indeed an allusion to 'noddy Nashe', then it more than strengthens Tobin's hypothesis of a link between Shakespeare's play and Have With You, it suggests that we may also need to change our understanding of the nature of that link. Two Gentlemen may not be just influenced by Nashe - it may be, in part, a satire on Nashe.

The presence of Crab in Two Gentlemen is clearly the most singular feature of the play. Yet no one has seriously tried to answer the simple question: why did Shakespeare take the then unprecedented step of creating a major role for a $d o g$ ? Of course, he may have simply thought it was a good idea at the time, but it was a sufficiently unusual thing to do to cause us to suspect some other motive, particularly when we remember that Lance and Crab were probably last-minute additions to a play completed in haste, presumably to meet some commercial imperative. Might Crab be a topical allusion of some kind?

Crab drifts in and out of Two Gentlemen, but he is most prominent in the two long soliloquies which frame Lance's appearances in the play. In the first soliloquy (Act 2, Scene 3), Lance launches immediately into a lengthy discourse about weeping, contrasting his and his family's floods of tears with the tearless behaviour of Crab. There is a notable focus on confused identity, bringing to the foreground suspicions about who exactly Lance and Crab are meant to be: 'I am the dogge: no, the dogge is himselfe, and I am the dogge: oh, the dogge is me, and I am my selfe: I; so, so'.

In Lance's final soliloquy (Act 4, Scene 4), far from the Crab unmoved to tears of the first soliloquy, we get the Crab moved far too much by his bladder, thrusting himself into the company of other dogs, pissing under the table and, worse, 'making water against a Gentlewomans farthingale'. It is this final image of Crab, I suggest, that most reveals Shakespeare's real intention in creating such a prominent role for a dog. 
To sum up: we have a play that could have been written in 1597, or even 1598; a play heavily influenced by, and possibly even a satire on, Thomas Nashe; a play which unprecedently introduces a dog as a major character; a play in which the Clown (probably a last-minute addition to the play), has a long final soliloquy (suffused with words common to a passage in Nashe), about the disgraceful behaviour of a dog who has caused havoc by, among other things, 'making water against a Gentlewomans farthingale'. The year: 1597 or 1598; the object of satire: Nashe; the cause of embarrassment: a scapegrace dog; the offended person: 'a Gentlewoman'. Could Crab be a topical satire on The Isle of Dogs affair?

The text of The Isle of Dogs has not come down to us, so we know frustratingly little about the play itself. What we do know is that in July 1597 a play of that name was performed at one of the theatres on the Bankside. The Privy Council was unhappy with it, describing it as a 'lewd plaie...contanynge very seditious and sclanderous matter', and ordered all the public theatres closed for the rest of the summer. Nashe was held to be primarily responsible for the play, but escaped the authorities by fleeing to Great Yarmouth. Ben Jonson was also implicated, both as co-author and actor, but did not escape punishment, being imprisoned, along with two other actors, in the Marshalsea. An order for their release was given on October 2. The Isle of Dogs itself was a peninsula in the Thames known for its wet, marshy conditions. It has been suggested that the play "may have glanced at members of the court circle and possibly at the queen herself, whose palace at Greenwich lay opposite the Isle of Dogs, down river from the city ${ }^{21}$.

Bearing the Isle of Dogs affair in mind, Lance's final soliloquy may be read anew. Firstly, we may note that the imagery is evocative of the actual Isle of Dogs, being somewhat 'watery': 'sau'd from drowning'; 'a pissing while'; 'make water against' (and Crab we already know to be a cur who does not 'shedde one teare'). Secondly, the dominant theme is of punishment: 'hang'd for't', 'suffer'd for't', 'whip the dog', 'sat in the stockes', 'executed', 'stood on the Pillorie'. Lastly, we may note that the theme is of punishment escaped - like Nashe, Crab manages to avoid punishment for his outrageous behaviour. If the passage is not meant to allude to the Isle of Dogs affair, it is a surprisingly good fit for a coincidence.

Supposing that it is not a coincidence, can we see any other glances at Nashe or the Isle of Dogs affair in Two Gentlemen? Less obviously, there may be one in Lance's first soliloquy, where the dominant theme is of weeping. For if we turn yet again to Have With You we find Nashe specifically associating the idea of weeping with himself - and with a dog:

For mee...the fire of my wit will not bee spent, till...I get it to be worshipt as god of those whom it most confounds...I will compell them to fall downe and worship mee ere I cease or make an end, crying vpon their knees Ponuloi nashe, which is in the Russian tongue, Haue mercie vpon vs: but I will not haue mercie or be pacifide, till I haue left them so miserable, that very horses shal hardly abstaine from weeping for them, as they did for the death of Caesar; and if they haue but euer a dog that lou'd them, he shall die for griefe, to view his masters in that plight. 
This passage in Have With You looks very much like a cue for the creation of Crab, though if it was, Shakespeare inverted the imagery: instead of 'a dog 'that...shall die for griefe, to view his masters in that plight', we get Crab the hard-hearted dog who fails to weep at all for his master. It is the same image we find in Trimming where Lichfield mocks Nashe for his lack of tears over the Isle of Dogs affair:

...when an Asses eares hang downe toward the ground, tis a certaine signe of raine instant, then seeing thine eares not only hang toward the ground...how can it chuse but be a signe of great wet at hand? and to thee it should be a cause of perpetuall showers that should flow from thine eyes, but thou art drye, no droppe of grace from thine eyes. If taking away of thine eares could take away thy hearing...then thou shouldst not heare thy selfe raild on, laughed at, nor know thy selfe to be a mocking stocke to all the Country but there is a more plaine way made to thy hearing organs, so that thou shalt more lightly heare thy selfe euery where cald crop-card curre.

Here we have a Nashe 'euery where cald...curre', and failing to weep, though there is a 'great wet at hand'. It's Nashe, but it may as well be Crab. Again, coincidence seems unlikely. ${ }^{22}$

If Two Gentlemen does indeed contain allusions to Nashe's role in the Isle of Dogs scandal, might it not also contain some allusion to Jonson's role? Certainly, Nashe was seen as the prime mover in the affair, so we would not expect the same number of references to Jonson that we appear to find for Nashe, but there may be at least one oblique reference, which I will record here.

William Drummond of Hawthornden reported that Jonson had said of the Isle of Dogs affair that, 'In the tyme of his close inprisonment, under Queen Elizabeth, his judges could get nothing of him to all their demands but I and No. They placed two damn'd villains to catch advantage of him, with him, but he was advertised by his keeper: of the Spies he hath ane epigrame. ${ }^{, 23}$ It is not hard to imagine Jonson boasting of this stoicism at the time, and it is just possible that this is glanced at in these lines from Two Gentlemen:

Speed:

But tell me true, wil't be a match?

Launce:

Aske my dogge, if he say I, it will: if hee say no, it will: if hee shake his taile, and say nothing, it will.

Speed:

The conclusion is then, that it will.

Launce:

Thou shalt neuer get such a secret from me, but by a parable.

Perhaps there is also some of the recalcitrant Jonson in the mixture that is Crab. 
If it is true that Two Gentlemen is in part a satire on the Isle of Dogs affair, then we can say with certainty that Shakespeare's play must have been completed no earlier than July 1597, when The Isle of Dogs was performed, and cannot have been played any earlier than September 1597, when the theatres started to re-open. Given what seems to be very hasty composition on Shakespeare's part, the most likely scenario is that he threw Two Gentlemen together during the closure of the theatres in AugustSeptember 1597 in anticipation of the commercial opportunity available for a topical play when the theatres eventually re-opened. There is nevertheless a possibility that the date of composition may have been later than this. If the 'I and No' section of Two Gentlemen is indeed a reference to Jonson's boasting of his stoic behaviour while in prison, then the play is not likely to have been completed until October 1597 at the earliest, when Jonson was released from the Marshalsea.

A precise dating of Two Gentlemen may rest on how we evaluate the relationship between Shakespeare's play and Lichfield's Trimming. I noted earlier that a passage in Trimming about Nashe failing to shed tears and being called a cur may be connected with Lance's first soliloquy. It is possible that Trimming may also contain echoes of Lance's final soliloquy, where two passages in Lichfield linked by the idea of pregnancy are reminiscent of Shakespeare's lines: 'the ouer pregnant dog (we see) bringeth forth blinde puppies' reminding us of 'one that I brought vp of a puppy: one that I sau'd from drowning, when three or foure of his blinde brothers and sisters went to it', and 'Againe, (among the Aegiptians) Saturne was called Kyon, because as a pregnant woman, he begat all things of himselfe and in himselfe; and in antique time they worshipped dogges' reminding us of 'one that takes vpon him to be a dog indeede, to be, as it were, a dog at all things'.

If there is indeed a connection between Two Gentlemen and Trimming, then the direction of influence will impact on our understanding of the date of Shakespeare's play. If Trimming was influenced by Two Gentlemen then the latter must have been completed by the end of 1597, since Lichfield's work was published in 1597. Alternatively, if Two Gentlemen was influenced by Trimming it is possible that Shakespeare's play may not have been completed till as late as 1598 .

There is some warrant for a date of 1598. Within the first few lines of Two Gentlemen, Shakespeare makes a direct reference to Hero and Leander. ${ }^{24}$ Such a reference could have been made at any time, but it would have had special relevance in 1598 when Marlowe's Hero and Leander was published for the first time, and like the running joke on 'Noddy' in the first scene, the reference comes suspiciously early in the play. Shakespeare may have included it to reflect the interest generated by the release of Marlowe's poem. If so, Two Gentlemen was probably written and performed within the first few months of 1598, since we know that Blount's first edition was published before 2 March 1598, when the copyright was assigned to another publisher. 
The likelihood that Two Gentlemen contains elements of satire on the Isle of Dogs affair, and was thus written later than July 1597, may throw significant new light on another important play of the time. For Two Gentlemen was not the only play of the late 1590s where a dog plays an intriguingly prominent part. The other play was, of course, Every Man Out Of His Humour, written by that co-perpetrator of the scandalous Isle of Dogs, Ben Jonson.

Like the presence of Crab in Two Gentlemen, the presence of Puntarvolo's dog, Chance, in Every Man Out has been strangely underexplored. Though not so dramatically prominent as Crab, Chance is similarly not just a 'stray' but 'at the centre of a web of dog-related imagery spreading through the play' ${ }^{25}$, and it is odd that so little critical attention has been given to the likelihood that Chance is partly a reference to the Isle of Dogs affair. Helen Ostovich suggested a connection, but only an 'oblique' one. ${ }^{26}$ However, contemporary audiences would surely have thought that extended canine imagery in a play by Ben Jonson in 1599 could not be anything other than a reference to The Isle of Dogs. The affair had not faded from public awareness at that stage; Meres was still referring to it in late 1598, and the publication of Nashe's Lenten Stuffe in 1599 would have reawakened interest.

The possibility of a link between Jonson's Chance and Shakespeare's Crab has also attracted little critical attention, though doubtless this has been affected by the belief that Two Gentlemen was an early play of Shakespeare's, and thus separated from Every Man Out by a considerable number of years. ${ }^{27}$ However, if Shakespeare used a dog in Two Gentlemen to satirise the Isle of Dogs affair, it becomes clear that Jonson's extensive use of a dog in Every Man Out, far from being coincidental, is probably in part a direct satirical response to Shakespeare's original satire. Certainly, Jonson appears to have had Shakespeare very much on his mind during Every Man Out. There are allusions in the play to Julius Caesar and Henry IV, and probably to Henry $V$ as well ${ }^{28}$, and it is even possible that Jonson takes a personal swipe at Shakespeare, using the character of Sogliardo to mock his social pretensions in acquiring a coat of arms ${ }^{29}$. To all this focus on Shakespeare in Every Man Out we can probably now add an extended reference to Two Gentlemen.

Every Man Out, like Two Gentlemen, may also be connected with Lichfield's Trimming. Jonson notably has his dog poisoned. This harsh treatment of Chance may have been influenced by a passage where Lichfield lampoons the whole Isle of Dogs affair, recounting a number of historical dog stories, one of which involves 'a dogge that was an excellent Actor... a dogge to be poisoned and reuiue againe... he eate the poyson, and...stackered vp and downe, reeling backward and forward... and at last fell downe, stretcht himselfe vpon the stage, and lay for dead. Soone after...by little and little he began to mooue himselfe...as though he awaked from a deepe sleepe...then he arose... which thing... mooued wonderfull admiration...in all...that were spectators.'

Jonson's poisoning of Chance seems very much like an ironic reversal of Lichfield's resurrected actor dog. Like Lichfield's dog, Chance's dying is somewhat drawn-out. Macilente poisons him in Act 5, Scene 1, but he is still alive in Scene 3, 'giving up the ghost in the wood-yard' ('Heart, is he not dead yet!' says Macilente), and there is still some doubt about his death in Scene 4, when Macilente tells Carlo Buffone that 'the passionate knight is shedding funeral tears over his departed dog, ${ }^{30}$ and Carlo raises 
Puntarvolo's hopes that Chance may yet be saved ('But for your dog, sir Puntarvolo, if he be not out-right dead, there is a friend of mine, a quack-salver, shall put life in him again, that's certain'), only for these hopes to be immediately dashed by Fungoso: ' $\mathrm{O}$, no, that comes too late'. There is no miraculous recovery from poison for this actor dog, he's stone dead. It may be Jonson's way of laying the Isle of Dogs affair, and all satire on it, to rest.

\section{JOHN PEACHMAN}

Sydney

${ }^{1}$ Kurt Schlueter (ed.), The Two Gentlemen of Verona (Cambridge, 1990), 1.

${ }^{2}$ Stanley Wells and Gary Taylor, et al., William Shakespeare: A Textual Companion (NY, 1997), 109.

${ }^{3}$ Jeffrey Masten, 'The Two Gentlemen of Verona', A Companion to Shakespeare's Works, Volume III: The Comedies, ed. Jean E. Howard and Richard Dutton (Oxford, 2003), 278.

${ }^{4}$ Clifford Leech (ed.), The Two Gentlemen of Verona (London, 1969), lxxi.

${ }^{5}$ Schlueter, 4.

${ }^{6}$ J.J.M. Tobin, 'Nashe And The Two Gentlemen Of Verona', $N \& Q$, (April 1981), 122-3.

${ }^{7}$ William C. Carroll (ed.), The Two Gentlemen of Verona (London, 2004), 128.

${ }^{8}$ When referring to Tobin's paper, I have retained the line and page numbering he quotes.

${ }^{9}$ Chadwyck-Healey Literature Online (LION) database.

${ }^{10}$ These two sequences of words also occur in Harvey's Pierce's Supererogation, but not in close proximity.

${ }^{11}$ Leech, xv.

${ }^{12}$ Leech, xxvii - xxviii.

${ }^{13}$ Richard Beadle, 'Crab's Pedigree', English Comedy, ed. Michael Cordner, Peter Holland and John Kerrigan (Cambridge, 1994), 13-14.

${ }^{14}$ All quotes from Two Gentlemen are from the 1623 Folio text. All underlining throughout the paper is mine for emphasis.

15 Tobin lists 'noddy' as occurring twice within a few lines, but it actually occurs three times.

${ }^{16}$ Leech, xxxviii.

${ }^{17}$ Thomas Nashe, Haue vvith you to Saffron-vvalden (London, 1596).

${ }^{18}$ Gabriel Harvey, Pierces supererogation (London, 1593).

${ }^{19}$ Richard Lichfield, The Trimming of Thomas Nashe Gentleman (London, 1597).

${ }^{20}$ Leech, 8.

${ }^{21}$ Ian Donaldson, 'Jonson, Benjamin (1572-1637)', Oxford Dictionary of National Biography (Oxford University Press, 2004).

${ }^{22}$ I will also note that at least one scholar has argued that the idea of weeping in general was associated with Nashe. See H.C.Hart, 'Ben Jonson, Gabriel Harvey, and Nashe', N\&Q (Nov. 21,1903), 403. However, Hart's argument by itself is not over-convincing.

${ }^{23}$ Shakespeare Society, Notes of Ben Jonson's Conversations with Willam Drummond of Hawthornden (London, 1842), 19.

${ }^{24}$ It is curious that in this reference to Hero and Leander Shakespeare adds a series of jokes about shoes/boots. An extended series of jokes on shoes is, of course, a notable feature of Lance's first soliloquy. Marlowe's father was a cobbler, so there may be some glance at that, but one wonders if there may not be some topical joke about shoes that we have lost the key to, perhaps in The Isle of Dogs itself.

${ }^{25}$ Matthew Steggle, 'Review of Ben Jonson, Every Man In His Humour and Every Man Out of His Humour', Early Modern Literary Studies 7.3 (January 2002), 8.8.

${ }^{26}$ Helen Ostovich (ed.), Every Man Out of His Humour (Manchester, 2001), 29.

${ }^{27}$ Anne Barton is one exception: 'It seems doubtful that Puntarvolo in Every Man Out of His Humour would have been accompanied by so palpably engaging and omnipresent a dog had Jonson not been remembering Launce and his friend Crab in The Two Gentlemen of Verona.' in 'Shakespeare and Jonson', Shakespeare, Man of the Theater: Proceedings of the Second Congress of the International Shakespeare Association, 1981 (Newark, 1983), 161.

${ }^{28}$ James P. Bednarz, 'When Did Shakespeare Write The Choruses of Henry V?', $N \& Q$ (December 2006), 486-9.

${ }^{29}$ The identification can, and has been, disputed, but a significant number of scholars have accepted it. 
30 Like Lance, Puntarvolo obviously has no problem weeping. 